\title{
Functional Variants of Fc Gamma Receptor (FCGR2A) and FCGR3A Are Not Associated with Susceptibility to Systemic Sclerosis in a Large European Study (EUSTAR)
}

\author{
BEHROOZ Z. ALIZADEH, JASPER BROEN, BLANCA RUEDA, ROGER HESSELSTRAND, DIRK WUTTGE, \\ CARMEN SIMEON, NORBERTO ORTEGO-CENTENO, MIGUEL A. GONZALEZ-GAY, ANNA PROS, \\ ARIANE HERRICK, JANE WORTHINGTON, CHRISTOPHER DENTON, CARMEN FONSECA, \\ GABRIELA RIEMEKASTEN, MADELON C. VONK, FRANK van den HOOGEN, SERENA GUIDUCCI, \\ MARCO MATUCCI-CERINIC, RAFAELLA SCORZA, LORENZO BERETTA, PAOLO AIRÓ, MARIEKE COENEN, \\ JAVIER MARTIN, BOBBY P.C. KOELEMAN, TIMOTHY R.D.J. RADSTAKE, and EUSTAR
}

\begin{abstract}
Objective. To investigate the possible role of FCGR2A 519A $>\mathrm{G}$ and FCGR3A 559A $>\mathrm{C}$ functional polymorphisms in the genetic predisposition to susceptibility to systemic sclerosis (SSc) or clinical phenotype.

Methods. A total of 1566 patients with SSc and 2271 geographically matched controls were included in our study. We analyzed the genotype and allele frequencies of the FCGR2A 519A $>\mathrm{G}$ and $F C G R 3 A$ 559A $>$ C functional variants in 6 independent European cohorts of white patients with SSc, and white controls. The cohorts comprised 165 Dutch patients with SSc and 1326 controls, 236 Spanish patients with SSc and 257 controls, 267 German patients with SSc and 270 controls, 202 Swedish patients with SSc and 261 controls, 416 Italian patients with SSc and 157 controls, and additionally 280 English patients with SSc. Genotyping was performed using Taqman $5^{\prime}$ allelic discrimination assay. The study reached a $99 \%$ power to detect the effect of a polymorphism at an OR of 1.3 .

Results. Neither FCGR2A 519A>G nor FCGR3A 559A>C was significantly associated with susceptibility to SSc. We did not find an association with specific disease phenotypes, limited or diffuse cutaneous involvement, autoantibody profiles, or pulmonary involvement.

Conclusion. Our study strongly suggests the lack of a role for the FCGR2A 519A $>\mathrm{G}$ and FCGR3A $559 \mathrm{~A}>\mathrm{C}$ polymorphisms in SSc susceptibility or clinical phenotype in 6 independent European cohorts. (First Release June 15 2010; J Rheumatol 2010;37:1673-9; doi:10.3899/jrheum.091259)
\end{abstract}

Key Indexing Terms:

FC GAMMA RECEPTORS SYSTEMIC SCLEROSIS GENETICS ASSOCIATION STUDY

From the Department of Medical Genetics, University Medical Center Utrecht, Utrecht; Department of Rheumatology and the Department of Human Genetics, Radboud University Nijmegen Medical Center,

Nijmegen; Department of Rheumatology, Sint Maartenskliniek, Nijmegen, The Netherlands; Instituto de Parasitología y Biomedicina, CSIC; Servicio de Medicina Interna, Hospital Clinico Universitario Granada, Granada; Servicio de Medicina Interna, Hospital Vall d'Hebron, Servicio de Reumatologia, Hospital Del Mar, Barcelona; Servicio de Reumatologia, Hospital Xeral-Calde, Lugo, Spain; Department of Rheumatology, Lund University Hospital, Lund, Sweden; Rheumatic Diseases Centre, University of Manchester, Salford Royal NHS Foundation Trust; Centre for Rheumatology, Royal Free and University College Medical School, London, United Kingdom; Department of Rheumatology and Clinical Immunology, Charité University Hospital, Berlin, Germany; Department of BioMedicine, Division of Rheumatology, AOUC, Florence; Referral Center for Systemic Autoimmune Diseases, University of Milan, Milan; and Servizio di Reumatologia e Immunologia Clinica, Spedali Civili, Brescia, Italy.

Supported by a grant from the Netherlands Organization for Health Research and Development (ZonMw; grant number 016.096.121) and in part by Junta de andalucia, grupo CT@-180,Spain, and by the VIDI laureate from the Dutch Organization of Research (NWO).
B.Z. Alizadeh, MD; B.P.C. Koeleman, MD, Department of Medical Genetics, University Medical Center Utrecht; J. Broen, MD; M.C. Vonk, MD, PhD; T.R.D.J. Radstake, MD, PhD, Department of Rheumatology, Radboud University Nijmegen Medical Center; B. Rueda, MD; J. Martin, $M D, P h D$, Instituto de Parasitología y Biomedicina, CSIC;

R. Hesselstrand, MD; D.M. Wuttge, MD, Department of Rheumatology, Lund University Hospital; C.P. Simeon, MD, Servicio de Medicina Interna, Hospital Vall d'Hebron; N. Ortego-Centeno, MD, Servicio de Medicina Interna, Hospital Clinico Universitario; M.A. Gonzalez-Gay, MD, Servicio de Reumatologia, Hospital Xeral-Calde; A. Pros, MD, Servicio de Reumatologia, Hospital Del Mar; A. Herrick, MD; J. Worthington, MD, Rheumatic Diseases Centre, University of Manchester, Salford Royal NHS Foundation Trust; C. Denton, MD; C. Fonseca, MD, Centre for Rheumatology, Royal Free and University College Medical School; G. Riemekasten, MD, Department of Rheumatology and Clinical Immunology, Charité University Hospital; F. van den Hoogen, MD, Department of Rheumatology, Sint Maartenskliniek; S. Guiducci, MD; M. Matucci-Cerinic, MD, Department of BioMedicine, Division of Rheumatology, AOUC; R. Scorza, MD; L. Beretta, MD, Referral Center for Systemic Autoimmune Diseases, University of Milan; P. Airó, MD, Servizio di Reumatologia e Immunologia Clinica, Spedali Civili; M. Coenen, PhD, Department of Human Genetics, Radboud University Nijmegen Medical Center.

\section{Personal non-commercial use only. The Journal of Rheumatology Copyright (C) 2010. All rights reserved.}


Address correspondence to Dr. T.R.D.J. Radstake, Department of Rheumatology, Radboud University Nijmegen Medical Center, Geert Grooteplein 8, $6500 \mathrm{HB}$ Nijmegen, The Netherlands. E-mail: T.Radstake@reuma.umcn.nl

Accepted for publication March 18, 2010.

Systemic sclerosis ( $\mathrm{SSc}$ ) is a systemic connective tissue disorder characterized by fibrosis of the skin and visceral organs. SSc is a complex autoimmune disease whose pathogenic hallmarks are endothelial cell death and immune aberrations including the presence of activated $\mathrm{T}$ cells and antibody production by B cells. The etiology of SSc remains obscure, but the disease is likely to result from the interplay of genetic and environmental factors.

In SSc, many cell types have been proposed as key players in the complex network of proinflammatory mediators. For instance, fibroblasts are involved in the production of the extracellular matrix and the fibrosis-inducing cytokine transforming growth factor $\beta$ (TGF- $\beta$ ), while antigen-presenting cells (APC) such as dendritic cells (DC), macrophages, and B cells have been demonstrated to support the profibrotic environment and autoantibody production. Further, the potential role of APC in SSc has been suggested by several observations. First, APC infiltration is one of the early features of skin pathology in patients with $\mathrm{SSc}^{1,2}$. APC accumulate perivascularly, where they become activated and produce a wide array of chemotactic factors, which results in the chemoattraction of many other immune effector cells, including monocytes, DC, T cells, and fibroblasts. Second, the degree of mononuclear cell infiltration in the skin of patients with SSc correlates well with both the degree and progression of skin thickening ${ }^{3}$.

How APC become activated is unknown but several mechanisms have been proposed, including binding of $\mathrm{Fc}$ gamma receptors $(\mathrm{Fc} \gamma \mathrm{R})$. In men, $\mathrm{Fc} \gamma \mathrm{R}$ can be divided into 3 classes. The Fc $\gamma R I$ is a high-affinity receptor that mainly

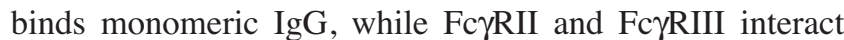
preferentially with immune complexes $s^{4,5,6,7}$. Following ligand binding, Fc $\gamma R I$, Fc $\gamma$ RIIa, and Fc $\gamma$ RIII are activating receptors while Fc $\gamma \mathrm{RIIb}$ is the only inhibitory receptor.

Several studies have shown that Fc $\gamma \mathrm{R}$ triggering by immune complexes determines APC phenotype and behavior in numerous autoimmune conditions as well as in tumor immunity ${ }^{8,9,10,11}$. Genetic studies have focused on these receptors and have associated the functional variant in Fc $\gamma \mathrm{R}$ genes with several autoimmune diseases, demonstrating a role in susceptibility or clinical phenotype of rheumatoid arthritis (RA), systemic lupus erythematosus (SLE), vasculitis, and Sjögren's syndrome ${ }^{12,13}$. Two polymorphisms are of special interest: FCGR2A $519 \mathrm{~A}>\mathrm{G}$ and FCGR3A $559 \mathrm{~A}>\mathrm{C}$. They pose a change in amino acids, subsequently affecting the binding affinity of the FCGR2A and $F C G R 3 A^{7}$. This might have implications in SSc pathology. Both high-affinity alleles may increase capture of IgG opsonized pathogens or $\mathrm{IgG}$ immune complexes and process them directly into the antigen-processing pathway, which results in more efficient presentation of self-antigens. On the other hand, the low-affinity alleles bind fewer immune complexes and could therefore reduce inflammatory response. In addition, FCGR2A is able to respond to surface-bound IgG by enhancing leukocyte attachment. In SSc, IgG against endothelial cells is present; subjects carrying the high-affinity allele of the FCGR2A would be at more risk for a sustained inflammation that follows enhanced leukocyte adhe$\operatorname{sion}^{14,15}$. On the basis of the functional evidence for involvement of $\mathrm{Fc} \gamma \mathrm{R}$ in multiple autoimmune diseases and a possible role in SSc pathology, we investigated whether the functional variants of the activating FCGR2A and FCGR3A genes are involved in SSc disease susceptibility and/or clinical phenotype, using a large cohort of patients with SSc collected within the EULAR (European League Against Rheumatism) Scleroderma Trials and Research consortium (EUSTAR).

\section{MATERIALS AND METHODS}

Study population. We performed our study within the framework of a large cohort of patients with SSc (EUSTAR). The local ethical committee from each center approved our study. Both patients and controls were included in our study after providing written informed consent. Our study population was composed of a total of 1566 white patients from 6 independent cohorts of European ancestry and 2271 ethnically matched controls (unrelated healthy individuals recruited in the same region as the patients with SSc). The Dutch cohort had 165 patients with SSc and 1326 controls; the Spanish, 236 patients and 257 controls; the German, 267 patients and 270 controls; the British, 280 patients; the Italian, 416 patients and 157 controls; and the Swedish, 202 patients and 261 controls. For the UK cohort, we did not have control data available. All the patients fulfilled the 1980 American College of Rheumatology classification criteria for $\mathrm{SSc}^{16}$.

Clinical characterization of patients. All patients included in our study were classified as having limited or diffuse SSc. When patients with SSc had cutaneous involvement distal to elbows, knees, and clavicles, they fulfilled definitions for limited scleroderma ${ }^{17}$. Those patients with SSc with proximal cutaneous changes were classified as having diffuse $\mathrm{SSc}^{18}$. Data regarding selective autoantibody status were not available in all patients with SSc. A total of 983 patients were assessed for the presence of antitopoisomerase (ATA) I (anti-Scl-70) antibodies and 902 for anticentromere antibodies (ACA). Involvement of the lungs was assessed in 750 patients with SSc according to the international guidelines ${ }^{19}$. The presence of pulmonary fibrosis was investigated by a computed tomography scan. Restrictive syndrome and diffusion capacity of the lungs was defined as a forced vital capacity $<75 \%$ of the predicted value and a diffusion capacity of the lung for carbon monoxide $<75 \%$ of predicted value.

FcGR genotyping. FCGR2A has 2 isoforms, which are encoded by a $\mathrm{G}$ to A substitution at nucleotide 519 of the FCGR2A (FCGR2A 519A $>\mathrm{G}$; National Center for Biotechnology Information single-nucleotide polymorphism (SNP) identification number rs1801274) ${ }^{20}$. The FCGR2A 519G allele encodes high-binding allele to $\operatorname{IgG} 2$ with a histidine at position 131 in the protein, while the FCGR2A 519A encodes the low-binding isoform where the histidine is replaced by an arginine ${ }^{20}$. The FCGR3A 559A $>\mathrm{C}$ polymorphism (rs396991) results in the expression of 2 receptor isoforms, i.e., an isoform with valine or phenylalanine at position 158 in the protein. The FCGR3A 559C allele encodes the valine isoform (i.e., V158 isoform) that is a high-binding allele to $\operatorname{IgG} 1$ and $\operatorname{IgG} 3$, while the FCGR3A $559 \mathrm{~A}$ allele encodes the 158 low-binding phenylalanine isoform (i.e., F158) 21,22 . Genotyping was performed using Taqman SNP genotyping assays (Applied 
Biosystems, Foster City, CA, USA) for FCGR2A 519A $>$ G (ABI assay identification number C_9077561_20) and for FCGR3A 559A $>\mathrm{C}$ (C_25815666_10). All assays were performed according to the manufacturer's protocol.

Data analysis. Genotype and allele frequencies were calculated by direct counting and were tested for Hardy-Weinberg equilibrium in each casecontrol set by using the FINETI program (http://ihg.gsf.de/cgi$\mathrm{bin} / \mathrm{hw} / \mathrm{hwa} 2 \mathrm{pl}$ ). Because a large proportion of previous studies and metaanalyses showed an association between FCGR2A 519GG and FCGR3A 559CC genotypes and susceptibility to different autoimmune diseases, we decided a priori to specifically compare the frequency of FCGR2A 519GG and FCGR3A 559CC genotypes of controls and patients ${ }^{23,24}$, using the chi-squared test. We used the Mantel-Haenszel (MH) test to estimate strata-weighted chi-squared test in a pooled analysis of all subjects and to calculate pooled OR and the corresponding 95\% CI. Homogeneity of OR were tested using Breslow-Day and Woolf Q methods. When there was a significant heterogeneity we applied random effects using the DerSimonian-Laird test to calculate the confidence limit for pooled OR. Regression analysis was used to estimate the age-adjusted effect of FCGR2A 519A $>\mathrm{G}$ and FCGR3A 559A $>\mathrm{C}$ alleles on SSc or its clinical phenotypes, while controlling for population differences. Data analysis was performed using SPSS version 15.0.

Estimation of the power of our study was performed using the Quanto v 0.5 software (Department of Preventive Medicine, University of Southern California, Los Angeles, CA, USA). For the pooled analysis of SSc and considering a medium minor allele frequency of 0.30 , our study reached a 99\% power to detect the effect of a polymorphism at an OR of 1.3. Under the same conditions, estimation of the power for the pooled analysis of SSc clinical analysis was $93 \%$ for limited cutaneous SSc (lcSSc; $n=1108), 73 \%$ for diffuse cutaneous SSc $(n=458), 77 \%$ for ACA $(n=1219)$, and $61 \%$ for $\operatorname{ATA}(\mathrm{n}=347)$.

\section{RESULTS}

General findings. In the whole cohort, comprising 1566 patients with SSc, $82.7 \%$ were women, which was similar across the different study populations (Table 1). The age of disease onset in patients with SSc was also comparable across different study cohorts. Similarly, the distribution of disease duration was comparable among the study cohorts, except for the Swedish cohort, who had shorter disease duration than the other cohorts. The Swedish cohort con- tained the most patients with lcSSc compared to the other study cohorts. The Swedish cohort also had the highest frequency of autoantibodies and pulmonary involvement compared to the other cohorts.

FCGR2A variant does not confer risk to SSc susceptibility. Overall, the frequency of the FCGR2A genotype distribution was quite similar among most populations investigated, both in controls and in patients with SSc (Table 2). The frequency of the FCGR2A 519AA genotype was clearly lower in the Swedish control and SSc populations compared to all other populations ( $\mathrm{p}=0.005$ in SSc and $\mathrm{p}=0.0021$ in controls). However, for all 6 populations investigated, the FCGR2A 519GG genotype was equally distributed among patients with SSc and controls in the Dutch $(\mathrm{p}=0.38)$, Spanish ( $\mathrm{p}=0.07)$, German $(\mathrm{p}=0.28)$, Swedish $(\mathrm{p}=0.38)$, and Italian $(\mathrm{p}=0.57)$ populations (Table 2$)$. Pooled analysis also did not reveal a difference in the frequency of FCGR2A alleles between patients with SSc and controls. Also, there was no difference in the frequency of the FCGR2A variant in patients with SSc and controls in a pooled analysis of the cohorts using the MH test ( $\mathrm{p}=0.45$; Figure 1$)$.

The FCGR3A variant does not confer risk to SSc susceptibility. For the FCGR3A polymorphism, no significant difference was observed in the frequency of FCGR3A polymorphism genotype between patients with SSc and controls in the Dutch $(\mathrm{p}=0.83)$, Spanish $(\mathrm{p}=0.90)$, German $(\mathrm{p}=$ $0.93)$, Swedish $(\mathrm{p}=0.45)$, and Italian $(\mathrm{p}=0.92)$ populations (Table 2). This finding persisted when we performed a pooled analysis of all the study populations (MH chi-squared $=0.22 ; \mathrm{p}=0.62$; Table 2). Also, there was no difference in the frequency of the FCGR3A 559CC genotype in patients with SSc and controls in the Dutch $(\mathrm{p}=$ $0.50)$, Spanish $(\mathrm{p}=0.92)$, German $(\mathrm{p}=0.78)$, Swedish $(\mathrm{p}=$ $0.21)$, Italian $(\mathrm{p}=0.77)$, or English $(\mathrm{p}=0.63)$ populations, or when data were pooled together $(\mathrm{MH}$ chi-squared $=$ $0.001 ; \mathrm{p}=0.99)$. Similarly, we found no difference in the

Table 1. Basic and clinical characteristics of the 6 European SSc cohorts.

\begin{tabular}{lcccccc}
\hline Characteristic & $\begin{array}{c}\text { The } \\
\text { Netherlands }\end{array}$ & Spain & Germany & Sweden & Italy & $\begin{array}{c}\text { United } \\
\text { Kingdom }\end{array}$ \\
\hline Patients with SSc, n & 165 & 236 & 267 & 202 & 416 & 280 \\
Female, \% & 71.7 & 83.8 & 87.4 & 76.9 & 95.5 & 81.3 \\
Age, yrs, SD & $56(13)$ & $58(13)$ & $56(12)$ & $56(15)$ & $55(13)$ & $59(12)$ \\
Disease duration, mo (SD) & $133(87)$ & $144(90)$ & $110(109)$ & $81(73)$ & $141(138)$ & $154(91)$ \\
Limited phenotype, \% & 77.5 & 70 & 52.5 & 82.1 & 70.7 & 74.6 \\
Positive ANA, (\%) & 97.1 & - & 94.4 & 83.1 & 74.8 & 78.4 \\
Positive Scl70, (\%) & 20.3 & 18.4 & 24.7 & 23.4 & 46.9 & 6.3 \\
Positive ACA, (\%) & 26.8 & 46.7 & 40.4 & 46.8 & 48.1 & 38.5 \\
Pulmonary fibrosis CT scan, \% & 30.4 & 30.7 & 36.2 & 44.9 & 38 & 43 \\
Low FVC (<75\% predicted), \% & 24.3 & 29.1 & 18.1 & 19.2 & 13.2 & 30 \\
Low DLCO (<75\% predicted), \% & 36.5 & 45.1 & 50.8 & 35.9 & 78 & 11.4 \\
\hline
\end{tabular}

ANA: antinuclear antibodies; Scl70: antitopoisomerase antibodies; ACA: anticentromere antibodies; FVC: forced vital capacity; DLCO: diffusion capacity of the lung for carbon monoxide; SSc: systemic sclerosis; CT: computed tomography. 
Table 2. Association analysis of the FCGR2A and FCGR3A genotypes and alleles with SSc in 6 European populations.

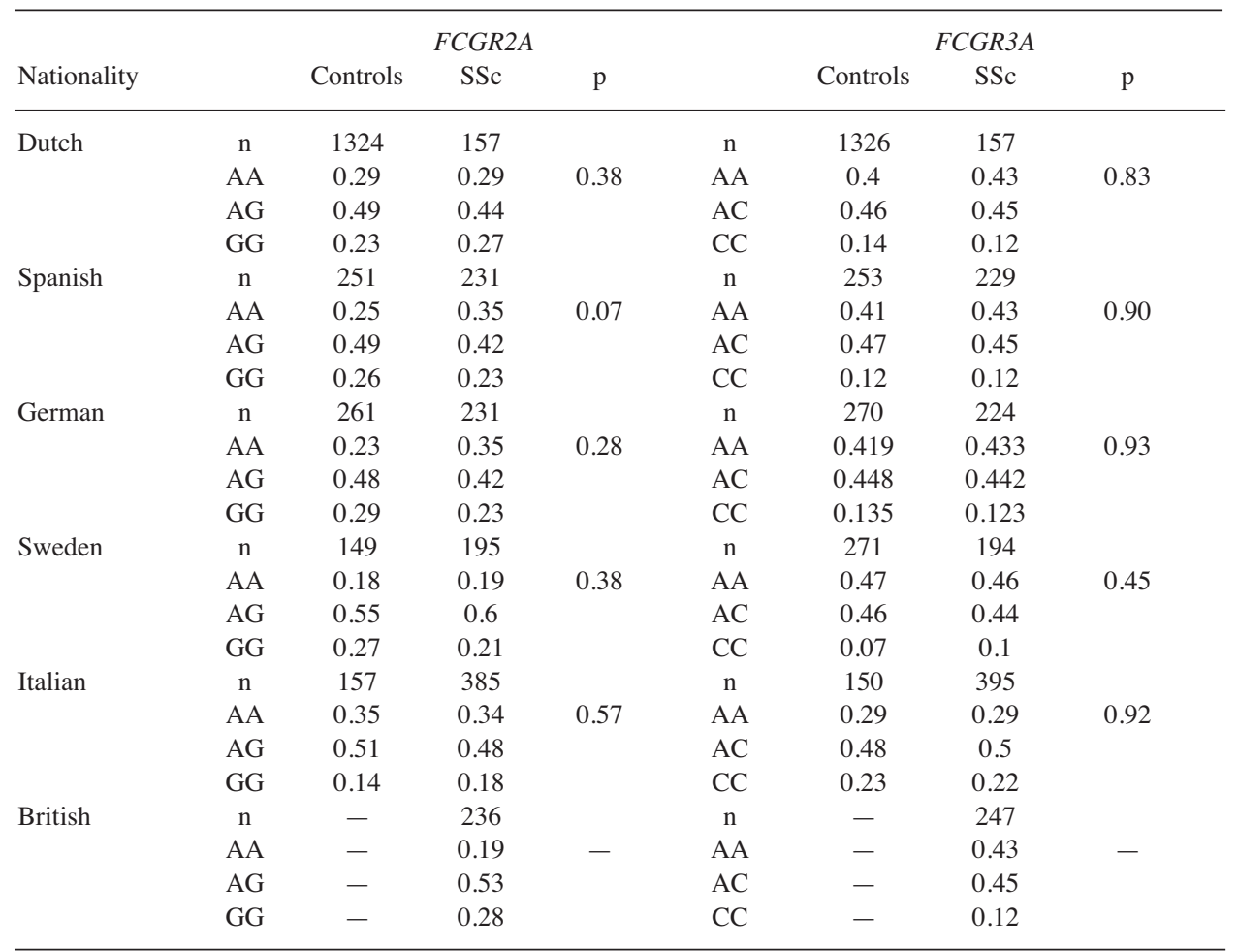

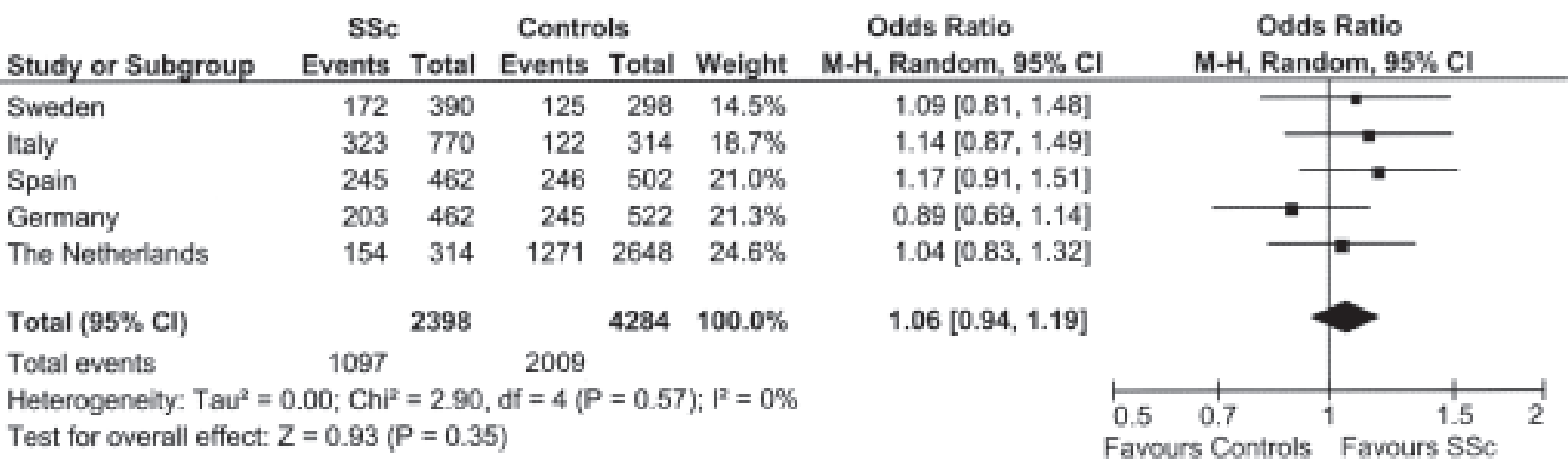

Figure 1. Effect of the FC $\gamma$ RIIa minor allele $(\mathrm{G})$ in 5 European populations, comparing healthy controls with patients with SSc, using the Mantel-Haenszel test for overall effect under random effects.

frequency of FCGR3A 559C allele in patients with SSc and controls in the Dutch $(p=0.36)$, Spanish $(p=0.75)$, German $(p=0.85)$, Swedish $(p=0.44)$, and Italian $(p=0.95)$ populations. Pooling data yielded similar results $(\mathrm{MH} \mathrm{p}=0.38$; Figure 2). Although there were no controls available from the UK, the distribution of both the genotypes as well as alleles in the patients with SSc was similar compared to that observed in the Dutch, Swedish, Spanish, and German populations, suggesting that a role for this genotype in SSc susceptibility is unlikely.

SSc phenotype is not associated with FCGR2A or FCGR3A genotype. Several reports indicate that $\mathrm{Fc} \gamma \mathrm{R}$ are involved in disease severity rather than susceptibility ${ }^{25,26}$. We tested this hypothesis and found no association of either FCGR2A or FCGR3A genotype with the patients' clinical characteristics, including the extent of skin involvement (Table 3, Table 4), the presence of autoantibodies, and pulmonary involvement (data not shown).

\section{DISCUSSION}

By studying one of the largest SSc cohorts, we found no association between the functional variants in FCGR2A and Personal non-commercial use only. The Journal of Rheumatology Copyright @ (2010. All rights reserved. 


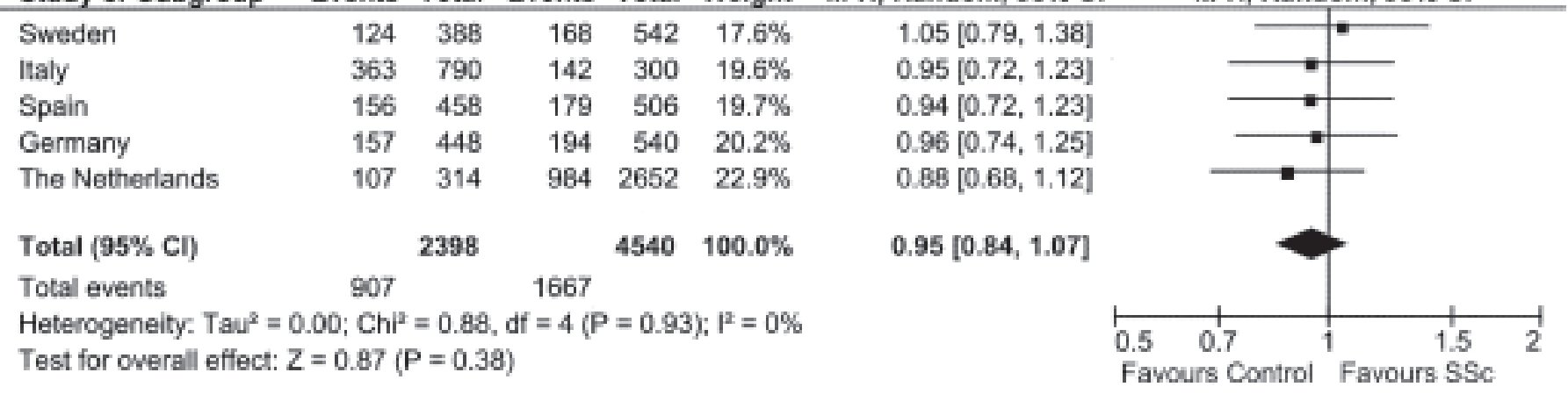

Figure 2. Effect of the FC $\gamma$ RIIIa minor allele (C) in 5 European populations, comparing healthy controls with patients with SSc, using the Mantel-Haenszel test for overall effect under random effects.

Table 3. Genotype frequencies of FCGR2A polymorphisms in 6 European SSc cohorts, comparing limited with diffuse cutaneous phenotypes.

\begin{tabular}{|c|c|c|c|c|c|}
\hline \multirow[b]{2}{*}{ Population } & \multicolumn{5}{|c|}{ Genotype Frequencies } \\
\hline & Phenotype & AA & AG & GG & $\mathrm{p}$ \\
\hline \multirow[t]{2}{*}{ Spanish } & Limited, $\mathrm{n}=133$ & 0.248 & 0.459 & 0.293 & \\
\hline & Diffuse, $\mathrm{n}=59$ & 0.203 & 0.492 & 0.305 & 0.794 \\
\hline \multirow[t]{2}{*}{ Dutch } & Limited, $\mathrm{n}=101$ & 0.277 & 0.475 & 0.248 & \\
\hline & Diffuse, $n=30$ & 0.167 & 0.466 & 0.367 & 0.313 \\
\hline \multirow[t]{2}{*}{ Swedish } & Limited, $\mathrm{n}=140$ & 0.207 & 0.586 & 0.207 & \\
\hline & Diffuse, $\mathrm{n}=55$ & 0.200 & 0.636 & 0.164 & 0.775 \\
\hline \multirow[t]{2}{*}{ German } & Limited, $\mathrm{n}=103$ & 0.359 & 0.369 & 0.272 & \\
\hline & Diffuse, $\mathrm{n}=88$ & 0.341 & 0.443 & 0.216 & 0.523 \\
\hline \multirow{2}{*}{ Italian } & Limited, $\mathrm{n}=227$ & 0.335 & 0.476 & 0.189 & \\
\hline & Diffuse, $n=93$ & 0.430 & 0.419 & 0.151 & 0.263 \\
\hline \multirow[t]{2}{*}{ British } & Limited, $\mathrm{n}=170$ & 0.182 & 0.524 & 0.294 & \\
\hline & Diffuse, $\mathrm{n}=59$ & 0.203 & 0.576 & 0.220 & 0.55 \\
\hline
\end{tabular}

Table 4. Genotype and allele frequencies of FCGR3A polymorphisms in 6 European SSc cohorts, comparing limited with diffuse phenotypes.

\begin{tabular}{|c|c|c|c|c|c|}
\hline \multirow[b]{2}{*}{ Population } & \multirow[b]{2}{*}{ Phenotype } & \multicolumn{3}{|c|}{ Genotype Frequencies } & \multirow[b]{2}{*}{$\mathrm{p}$} \\
\hline & & AA & $\mathrm{AC}$ & $\mathrm{CC}$ & \\
\hline \multirow[t]{2}{*}{ Spanish } & Limited, $\mathrm{n}=132$ & 0.416 & 0.47 & 0.114 & \\
\hline & Diffuse, $\mathrm{n}=57$ & 0.474 & 0.421 & 0.105 & 0.767 \\
\hline \multirow[t]{2}{*}{ Dutch } & Limited, $\mathrm{n}=101$ & 0.386 & 0.465 & 0.149 & \\
\hline & Diffuse, $n=29$ & 0.586 & 0.379 & 0.034 & 0.089 \\
\hline \multirow[t]{2}{*}{ Swedish } & Limited, $\mathrm{n}=141$ & 0.468 & 0.404 & 0.128 & \\
\hline & Diffuse, $n=53$ & 0.434 & 0.528 & 0.038 & 0.107 \\
\hline \multirow[t]{2}{*}{ German } & Limited, $\mathrm{n}=97$ & 0.464 & 0.423 & 0.113 & \\
\hline & Diffuse, $\mathrm{n}=88$ & 0.466 & 0.409 & 0.125 & 0.964 \\
\hline \multirow[t]{2}{*}{ Italian } & Limited, $\mathrm{n}=232$ & 0.302 & 0.509 & 0.189 & \\
\hline & Diffuse, $\mathrm{n}=98$ & 0.245 & 0.449 & 0.306 & 0.066 \\
\hline \multirow[t]{2}{*}{ British } & Limited, $\mathrm{n}=179$ & 0.447 & 0.447 & 0.106 & \\
\hline & Diffuse, $\mathrm{n}=61$ & 0.410 & 0.475 & 0.115 & 0.88 \\
\hline
\end{tabular}

FCGR3A genes and SSc susceptibility or clinical characteristics in 6 populations throughout Europe. The role of FCGR genes has been thoroughly investigated globally in many diseases with often inconsistent results, which can be attributed to fairly small study populations.
Several lines of evidence suggest a role for FCGR polymorphisms in the pathogenesis of SSc. Boros, et al described the presence of anti-Fc $\gamma \mathrm{R}$ antibodies in sera from tight-skin mice and patients with SSc that suggests a dysfunction of the macrophage phagocytic system and inappro- 
priate stimulation of $\mathrm{Fc} \gamma \mathrm{R}$-bearing cells as one of the pathogenic mechanisms in $\mathrm{SSc}^{27,28,29}$. Moreover, SSc-associated autoantibodies bind to FcyR, thereby influencing the outcome of the immune response. For instance, ATA and ACA are $\mathrm{IgG}$ antibodies and are thought to form immune complexes in SSc, thus potentially crosslinking Fc $\gamma \mathrm{R}$ and inducing cell signaling $27,28,29$. More recently, SSc-associated antibodies against platelet-derived growth factor receptor have been found to mediate enhanced leukocyte function by activating $\mathrm{Fc} \gamma \mathrm{R}^{30}$. In addition, it was demonstrated that Fc $\gamma$ RIIa functions in concert with Toll-like receptor (TLR) 9 to take up immune complexes and stimulate plasmacytoid DC in SLE. Because DC were found to be activated by SSc serum, a phenomenon that was dependent upon the presence of TLR9, it is tempting to speculate that FcyRIIa is involved in $\mathrm{SSc}^{31}$.

We found no association of the 2 polymorphisms FCGR2A and FCGR3A in SSc. Several biases could mask an existing significant relationship between a genotype and a disease in association studies. However, it less likely that these biases played a role in our study. First, all samples were genotyped in 1 center, which lowers the chance of false-positive associations. Further, pooled analysis of the study cohorts provided sufficient power to detect a mild risk increase of 1.2 for any of the tested genotypes and SSc. And finally, patients were carefully characterized for both subjective and objective clinical features, each of which was further analyzed in relation to FCGR2A or FCGR3A genotypes. Therefore a role for bias due to heterogeneity among the patient groups is unlikely to cause a null finding. Despite various efforts, no healthy control DNA samples from the UK were available to include in our study. However, the genotype distribution in the English patients with SSc resembled those in the other SSc populations, and was similar to control populations reported in previous studies incorporating healthy controls from the UK, making a contribution of these variants to SSc in this cohort very unlike$1 y^{32,33}$. We persistently found no association of SSc as a clinical diagnosis or any of its clinical characteristics with the FCGR2A or FCGR3A genotypes. These results indicate that our findings form a true negative, and suggest that genetic alterations in the FCGR2A or FCGR3A genes do not play a key role in the immune aberrations observed in SSc.

Although FCGR2A and FCGR3A have been involved with several other immune diseases, our study suggests that the role of the 2 investigated variants in the FCGR2A and FCGR3A might be limited in SSc. Several explanations might be put forward to explain this. From a genetic point of view, we performed a direct testing strategy and examined only 2 common functional variants with probably a relatively low effect size on a relatively rare disease in the population. It might be that other variants in the FCGR2A and FCGR3A do play roles in SSc. On the other hand, it is still not clear to what extent common variants can explain SSc. To date, no genome-wide association study has been per- formed for SSc. Genome-wide association studies in other complex disorders such as RA and diabetes do indicate that common variants play a role in them. The upcoming genome-wide association studies in SSc might put more light on this challenging dilemma. We focused on the functional variants in only 2 FCGR genes. However, there are other FCGR genes and other types of genetic variations (e.g., copy number variation) that also cluster on chromosome 1q21-q24, and are associated with several autoimmune diseases. Interestingly, associations between copy number variations of $F C G R 2 B$ and lupus nephritis, SLE, and Wegener's granulomatosis have been reported ${ }^{34,35}$; we did not investigate these. Therefore, it remains unclear whether other types of genetic variations in the FCGR genes can affect susceptibility to SSc. From an immunological viewpoint, Fc $\gamma$ RIIa and Fc $\gamma$ RIIIa are only part of a very complex family of multiple Fc $\gamma \mathrm{R}$ subtypes. For instance, there is still debate about the exact contribution of FcyRIIIb in immune processes that recently gained even more interest after the identification of a copy number variant in this gene that was highly associated with SLE and $\mathrm{RA}^{36}$. In addition, the inhibitory Fc $\gamma$ RIIb has been shown to play a crucial role in many diseases. Finally, Fc $\gamma R I I c$ was recently identified as a single and independent entity. These observations indicate that the absence of association between FCGR2A and $F C G R 3 A$ with $\mathrm{SSc}$ justifies further research into the role of $F C G R 3 B, 2 B$, and $2 C$, and possible interactions between these receptors in SSc.

The FCGR2A and FCGR3A genes are not associated with SSc susceptibility and/or clinical phenotype. The rationale for the role of Fc $\gamma \mathrm{R}$ in SSc warrants further investigation into the potential role of other Fc $\gamma \mathrm{R}$ subtypes in this condition.

\section{ACKNOWLEDGMENT}

We thank Marieke Dekkers, Christel Brouwer, Sofia Vargas, and Gema Robledo for the collection of blood samples and subsequent isolation of DNA.

\begin{abstract}
APPENDIX. Other collaborators.
The AADEA (Andalusian Association of Autoimmune Diseases) group: Jose Luis Callejas, Hospital Clínico San Cecilio, Granada; Julio Sanchez-Román and Francisco J. García-Hernández, Servicio de Medicina Interna, Hospital Virgen del Rocio, Sevilla; Enrique De-Ramon and Mayte Camps, Servicio Medicina Interna, Hospital Carlos Haya, Málaga; M. Angeles Aguirre, Servicio de Reumatología, Hospital Reina Sofía, Córdoba; Rosa García-Portales, Servicio Medicina Interna, Hospital Virgen de la Victoria, Málaga.

EUSTAR coauthors: Jeannine Günther, Mike Becke, Department of Rheumatology and Clinical Immunology, Charité University Hospital, Berlin, Germany; Agneta Scheja, Izabela Bartosik, Department of Rheumatology, Lund University Hospital, Lund, Sweden; Mirko Scarsi, Servizio di Reumatologia ed Immunologia Clinica, Spedali Civili, Brescia, Italy.
\end{abstract}

\section{REFERENCES}

1. Mouthon L, Garcia de la Pena-Lefebvre P, Chanseaud Y, Tamby MC, Boissier MC, Guillevin L. [Pathogenesis of systemic scleroderma: immunological aspects]. Ann Med Interne 2002;153:167-78. 
2. Prescott RJ, Freemont AJ, Jones CJ, Hoyland J, Fielding P. Sequential dermal microvascular and perivascular changes in the development of scleroderma. J Pathol 1992;166:255-63.

3. Roumm AD, Whiteside TL, Medsger TA Jr, Rodnan GP. Lymphocytes in the skin of patients with progressive systemic sclerosis. Quantification, subtyping, and clinical correlations. Arthritis Rheum 1984;27:645-53.

4. Dijstelbloem HM, van de Winkel JG, Kallenberg CG. Inflammation in autoimmunity: receptors for IgG revisited. Trends Immunol 2001;22:510-6

5. Ravetch JV, Bolland S. IgG Fc receptors. Annu Rev Immunol 2001;19:275-90.

6. Ravetch JV, Lanier LL. Immune inhibitory receptors. Science 2000;290:84-9.

7. Salmon JE, Pricop L. Human receptors for immunoglobulin G: key elements in the pathogenesis of rheumatic disease. Arthritis Rheum 2001;44:739-50.

8. Amigorena S. Fc gamma receptors and cross-presentation in dendritic cells. J Exp Med 2002;195:F1-3.

9. Ioan-Facsinay A, de Kimpe SJ, Hellwig SM, van Lent PL, Hofhuis FM, van Ojik HH, et al. Fc gamma RI (CD64) contributes substantially to severity of arthritis, hypersensitivity responses, and protection from bacterial infection. Immunity 2002;16:391-402.

10. Kalergis AM, Ravetch JV. Inducing tumor immunity through the selective engagement of activating Fc gamma receptors on dendritic cells. J Exp Med 2002;195:1653-9.

11. Schuurhuis DH, Ioan-Facsinay A, Nagelkerken B, van Schip JJ, Sedlik C, Melief CJ, et al. Antigen-antibody immune complexes empower dendritic cells to efficiently prime specific CD8+ CTL responses in vivo. J Immunol 2002;168:2240-6.

12. Blank MC, Stefanescu RN, Masuda E, Marti F, King PD, Redecha $\mathrm{PB}$, et al. Decreased transcription of the human FCGR2B gene mediated by the $-343 \mathrm{G} / \mathrm{C}$ promoter polymorphism and association with systemic lupus erythematosus. Human Gen 2005;117:220-7.

13. Radstake TR, Franke B, Wenink MH, Nabbe KC, Coenen MJ, Welsing $\mathrm{P}$, et al. The functional variant of the inhibitory Fc gamma receptor IIb (CD32B) is associated with the rate of radiologic joint damage and dendritic cell function in rheumatoid arthritis. Arthritis Rheum 2006;54:3828-37

14. Gabrielli A, Montroni M, Rupoli S, Caniglia ML, DeLustro F, Danieli G. A retrospective study of antibodies against basement membrane antigens (type IV collagen and laminin) in patients with primary and secondary Raynaud's phenomenon. Arthritis Rheum 1988;31:1432-6.

15. Florey OJ, Johns M, Esho OO, Mason JC, Haskard DO Antiendothelial cell antibodies mediate enhanced leukocyte adhesion to cytokine-activated endothelial cells through a novel mechanism requiring cooperation between Fc gamma RIIa and CXCR1/2. Blood 2007;109:3881-9.

16. Preliminary criteria for the classification of systemic sclerosis (scleroderma). Subcommittee for scleroderma criteria of the American Rheumatism Association Diagnostic and Therapeutic Criteria Committee. Arthritis Rheum 1980;23:581-90.

17. LeRoy EC, Medsger TA Jr. Criteria for the classification of early systemic sclerosis. J Rheumatol 2001;28:1573-6.

18. LeRoy EC, Black C, Fleischmajer R, Jablonska S, Krieg T, Medsger TA Jr, et al. Scleroderma (systemic sclerosis): classification, subsets and pathogenesis. J Rheumatol 1988; 15:202-5.

19. Matucci-Cerinic M, D'Angelo S, Denton CP, Vlachoyiannopoulos P, Silver R. Assessment of lung involvement. Clin Exp Rheumatol 2003;21:S19-23.
20. Bredius RG, Derkx BH, Fijen CA, de Wit TP, de Haas M, Weening $\mathrm{RS}$, et al. Fc gamma receptor IIa (CD32) polymorphism in fulminant meningococcal septic shock in children. J Infect Dis 1994;170:848-53

21. Edberg JC, Wainstein E, Wu J, Csernok E, Sneller MC, Hoffman GS, et al. Analysis of Fc gamma RII gene polymorphisms in Wegener's granulomatosis. Exp Clin Immunogenet 1997; 14:183-95.

22. Salmon JE, Edberg JC, Kimberly RP. Fc gamma receptor III on human neutrophils. Allelic variants have functionally distinct capacities. J Clin Invest 1990;85:1287-95.

23. Alizadeh BZ, Valdigem G, Coenen MJ, Zhernakova A, Franke B, Monsuur A, et al. Association analysis of functional variants of the FcgRIIa and FcgRIIIa genes with type 1 diabetes, celiac disease and rheumatoid arthritis. Hum Mol Genet 2007;16:2552-9.

24. Karassa FB, Trikalinos TA, Ioannidis JP. Role of the Fc gamma receptor IIa polymorphism in susceptibility to systemic lupus erythematosus and lupus nephritis: a meta-analysis. Arthritis Rheum 2002;46:1563-71.

25. Morgan AW, Griffiths B, Ponchel F, Montague BM, Ali M, Gardner $\mathrm{PP}$, et al. Fc gamma receptor type IIIA is associated with rheumatoid arthritis in two distinct ethnic groups. Arthritis Rheum 2000;43:2328-34

26. Radstake TR, Petit E, Pierlot C, van de Putte LB, Cornelis F, Barrera P. Role of Fc gamma receptors IIA, IIIA, and IIIB in susceptibility to rheumatoid arthritis. J Rheumatol 2003;30:926-33.

27. Boros P, Muryoi T, Spiera H, Bona C, Unkeless JC. Autoantibodies directed against different classes of $\mathrm{Fc}$ gamma $\mathrm{R}$ are found in sera of autoimmune patients. J Immunol 1993;150:2018-24.

28. Boros P, Odin JA, Muryoi T, Masur SK, Bona C, Unkeless JC. IgM anti-Fc gamma $\mathrm{R}$ autoantibodies trigger neutrophil degranulation. J Exp Med 1991;173:1473-82.

29. Davis K, Boros P, Keltz M, Unkeless JC, Fleischmajer R. Circulating Fc gamma receptor-specific autoantibodies in localized and systemic scleroderma. J Am Acad Dermatol 1995;33:612-6.

30. Baroni SS, Santillo M, Bevilacqua F, Luchetti M, Spadoni T, Mancini M, et al. Stimulatory autoantibodies to the PDGF receptor in systemic sclerosis. N Engl J Med 2006;354:2667-76.

31. Kim D, Peck A, Santer D, Patole P, Schwartz SM, Molitor JA, et al. Induction of interferon-alpha by scleroderma sera containing autoantibodies to topoisomerase I: association of higher interferon-alpha activity with lung fibrosis. Arthritis Rheum 2008:58:2163-73

32. Morgan AW, Griffiths B, Ponchel F, Montague BM, Ali M, Gardner $\mathrm{PP}$, et al. Fc gamma receptor type IIIA is associated with rheumatoid arthritis in two distinct ethnic groups. Arthritis Rheum 2000;43:2328-34

33. Atsumi T, Caliz R, Amengual O, Khamashta MA, Hughes GR. Fc gamma receptor IIA H/R131 polymorphism in patients with antiphospholipid antibodies. Thromb Haemost 1998;79:924-7.

34. Aitman TJ, Dong R, Vyse TJ, Norsworthy PJ, Johnson MD, Smith $\mathrm{J}$, et al. Copy number polymorphism in Fcgr3 predisposes to glomerulonephritis in rats and humans. Nature 2006;439:851-5.

35. Fanciulli M, Norsworthy PJ, Petretto E, Dong R, Harper L, Kamesh $\mathrm{L}$, et al. FCGR3B copy number variation is associated with susceptibility to systemic, but not organ-specific, autoimmunity. Nat Genet 2007;39:721-3.

36. Willcocks LC, Lyons PA, Clatworthy MR, Robinson JI, Yang W, Newland SA, et al. Copy number of FCGR3B, which is associated with systemic lupus erythematosus, correlates with protein expression and immune complex uptake. J Exp Med 2008;205:1573-82. 